\title{
A COMPARATIVE STUDY ON THE OBSTETRIC SERVICES UTILIZATION BY INCOME CLASSES AMONG THE NATIONAL HEALTH INSURANCE BENEFICIARIES
}

\author{
Kyung Ha Kim, PhD', Rah Il Hwang, PhD², Ji Won Yoon, PhD², Ki-Jin Ryu, MD³, Soon-Cheol Hong, MD, PhD³ \\ 'Worker's Compensation Research Center, Korea Worker's Compensation and Welfare Service, Seoul; ${ }^{2}$ Department of Nursing, Suwon Women's College, Suwon; \\ ${ }^{3}$ Department of Obstetrics and Gynecology, Korea University Anam Hospital, Korea University College of Medicine, Seoul, Korea
}

\section{Objective}

This study was conducted to compare the trend of obstetrical care service and its performance, different kinds of common obstetrical disease, and different pattern of health care utilization by the classification of income among the National Health Insurance Beneficiaries.

\section{Methods}

This study was investigated on the base of data which were drawn from the "nationwide claim database of Korean National Health Insurance Corporation". Data were composed of the total cases related to pregnancy, childbirth, and the puerperium from 2004 to 2008. Subjects were divided into five income classes by the amount of medical insurance premium. Statistical analysis was performed using SAS program.

\section{Results}

In terms of the lowest income class, there was the lowest rate of admission but the highest rate of outpatient visits, which were remarkably increased during the last 2 years. The lowest income group showed higher rate of abortion (000-008), ectopic pregnancy and preeclampsia (010-016) but there was small number of delivery (080-084). The highest income group showed higher rate of multifetal gestation and elderly gravida. As they have higher income, they showed tendency to visit general hospital for admission care or outpatient care.

\section{Conclusion}

There were significant differences in obstetric services utilization and prevalence of common obstetrical disease according to income class. New strategy of public medical insurance is needed to support different disease category according to the socioeconomic status. Especially, institutional support should be considered for lower income women who are exposed to higher pregnancy complications.

Keywords: Income class; Obstetric outcomes; Abortion; Preeclampsia; Multifetal gestation

우리나라 2011년 총 출생아 수는 약 47만 12백 명으로 지난 30년 동안 절반 이상으로 감소하였고, 합계출산율은 1.24명으로 경제협력개 발기구(Organization for Economic Cooperation and Development) 국 가 중 최하위 수준이다[1]. 이러한 저출산 문제는 2000년대 초반부터 사회적으로 초미의 관심사로 부각되고 있으나 획기적 대책 마련 방안 을 제시하지 못하고 있는 실정이다. 출산율은 사회역동성과 미래발전 가능성과 관련되는 중요한 지표로서 지속적인 출산율 저하는 향후 국 가경쟁력을 약화시킬 수 있는 매우 심각한 문제이다. 이에 국가에서는 저출산의 원인에 대한 사회변화 파악과 이에 근거한 다양한 정책 방안 을 지속적으로 모색해 나가고 있다. 그 일환으로 건강보험에서는 산전 진찰에 대한 보험 급여 혜택, 자연분만 본인 부담 면제, 미숙아 본인 부 담 면제 및 임신부 출산지원금 지원 확대 등 임신, 출산 관련 급여 혜택 을 확대하여 임신부가 건강한 태아를 분만할 수 있는 출산 환경을 조성 하는데 기여하고자 노력하고 있다. 그러나 지금까지 이러한 임신, 출산
Received: 2012.5.4. Revised: 2012.8.24. Accepted: 2012.10.10.

Corresponding authors: Rah Il Hwang, PhD

Department of Nursing, Suwon Women's College, 72 Onjeong-ro,

Gwonseon-gu, Suwon 441-748, Korea

Tel: +82-31-290-8103 Fax: +82-31-290-8142

E-mail: hwangri@swc.ac.kr

Soon-Cheol Hong, MD, PhD

Department of Obstetrics and Gynecology, Korea University

Medical Center, Korea University College of Medicine, 73 Inchon-

ro, Seongbuk-gu, Seoul 136-705, Korea

Tel: +82-2-920-6602 Fax: +82-2-921-5357

E-mail: novak082@korea.ac.kr

This is an Open Access article distributed under the terms of the Creative Commons Attribution Non-Commercial License (http://creativecommons.org/licenses/ by-nc/3.0/) which permits unrestricted non-commercial use, distribution, and reproduction in any medium, provided the original work is properly cited.

Copyright $\odot$ 2012. Korean Society of Obstetrics and Gynecology 
을 장려하기 위한 건강보험 정책들은 임신부의 연령, 소득, 거주지 등 대상자별 특성을 고려하지 않고 일괄적으로 적용하였다는 한계점이 있 으며, 건강보험 정책이 실효성을 거두기 위해서는 임신부 중 고위험 집 단을 세분화하여 보다 적극적으로 지원할 필요성이 있는 것으로 지적 되고 있다[2].

더욱이 2005년 이후 다양한 건강보험의 보장성 강화 정책과 저소득 층을 보호하기 위한 사회안전망 강화 정책에도 불구하고 소득수준별 보건의료 이용의 형평성에 대한 문제는 지금까지 보건의료정책의 주 요 해결과제로 끊임없이 제기되고 있고, 기존 연구를 통해서도 소득계 층 간 의료불평등은 이미 보고된 바 있다[3,4]. 저소득층은 열악한 주거 환경, 영양 상태, 건강에 역행하는 생활습관 등으로 의료서비스에 대한 요구도가 높지만, 의료비에 대한 부담감으로 의료서비스 접근성이 비 교적 낮은 의료 취약 집단이다[5]. 특히 저소득층 여성은 빈곤, 장시간 노동, 임신과 출산으로 인한 스트레스 등으로 인해 산전진찰을 덜 받고 있으며, 임신중독증, 전치태반, 태반조기박리증, 조기 양수파수, 조산, 사산, 임신성 당뇨병, 산욕기 정신질환 등 임신 관련 합병증의 발생 빈 도가 높다[6,7]. 저소득층의 경우 고소득층보다 총 가구 수입 중 임신, 출산 관련 의료비가 차지하는 비중이 더 높기 때문에 의료서비스 이용 에 대한 제약이 더욱 많은 것으로 보고되고 있다[8-10]. 또한 임신 중 합병증을 동반하는 경우는 임신, 출산 의료비 부담이 가중되어 지속적 으로 가계 부담으로 작용할 수 있어 공공 차원의 지원 방안 모색이 필 요하다[8,9]. 그러나 국내 연구 중 소득계층별 여성들의 산과 보건의료 서비스 이용 특성에 대한 비교분석에 대한 구체적인 연구는 미미한 수 준이어서, 가구의 소득계층별 형평성 강화를 위한 차별화된 정책 방안 을 도출하기에는 한계가 있었다.

따라서 본 연구는 전국 건강보험가입자의 소득계층별 산과서비스 이 용 특성을 비교분석하여 향후 계층별 고위험 임신에 대한 효과적 지원 방안의 모색에 필요한 기초자료를 제공하는 데 목적이 있다. 본 연구의 구체적 목적은 첫째, 건강보험가입자의 소득계층별 산과서비스 이용 실적 추이를 파악, 둘째, 건강보험가입자의 소득계층별 산과코드(ICD000-099)별 진료실적을 비교분석하고, 셋째, 건강보험가입자의 소득 계층별 다빈도 질환을 비교분석하며, 마지막으로 건강보험가입자의 소 득계층별 산과 관련 의료기관 이용 양상을 비교하는 데 있다.

\section{연구대상 및 방법}

\section{1. 연구대상}

본 연구는 2004년 1월 1일부터 2008년 12월 31일까지 국민건강보 험공단에 청구된 전수 자료를 이용하였다. 건강보험급여자료 중 주 상 병코드가 임신, 출산 관련 상병코드(000-099)로 분류된 자료를 기초 자료로 활용하였다. 본 연구는 건강보험자만을 대상으로 하였으며, 의 료급여 대상자는 제외하였다.

\section{2. 연구내용 및 자료분석}

2004년부터 2008년까지 임신부의 소득수준별 산과 진료실적을 비 교분석하기 위해 건강보험급여자료를 각 연도말 건강보험 자격 및 보 험료 자료와 연결시켜 소득수준을 월보험료 5 분위 $(\mathrm{Q} 1<20 \%, 20 \% \leq$ $\mathrm{Q} 2<40 \%, 40 \% \leq \mathrm{Q} 3<60 \%, 60 \% \leq \mathrm{Q} 4<80 \%, \mathrm{Q} 5 \geq 80 \%$ )로 구분하 였고, 소득1분위(Q1)는 최저 소득 계층으로, 소득5분위(Q5)는 최고 소 득 계층으로 정의하였다. 소득 자료는 직장과 지역의 보험료 부과기 준이 달라 보험료 금액도 차이가 발생하므로 분위수로 구분하여 분석 하였다. 즉, 각 연도말을 기준으로 지역가입자와 직장가입자로 구분하 여 각각의 월보험료를 5 분위로 체크한 후, 분위수가 동일한 경우는 건 강보험 가입 종류(지역, 직장)가 다르더라도 소득수준은 동일한 것으로 간주하였다. 이 때 보험료 금액이 자료에서 확인되지 않은 청구건은 제 외시킨 후 소득수준별 임신, 출산 질환에 대한 의료이용 및 총 진료비 를 분석하였다. 건강보험급여자료를 통해 진료실 인원수, 의료기관 입 원 및 외래 방문일수, 공단부담금과 법정 본인부담금이 포함된 심사결 정 총 진료비(이하 총 진료비)를 산정하였고, 진료 형태가 입원일 경우 는 입원실 인원수, 입원건수, 입원 총 진료비로, 외래일 경우는 외래실 인원수, 외래일수, 외래 총 진료비로 구분하여 분석하였으며, 의료기관 종별로도 세분화하여 분석하였다. 입원 및 외래에서의 진료실 인원수 는 진료건이 중복된 자를 제외한 수치로 산출하였다. 5년간 입원 및 외 래 총 진료내역 비교 추이에서의 백분율은 입원과 외래를 구분하여 해 당년도의 분위수 전체 건 중 각 분위수 건이 차지하는 비율로 표시하 였고, 2008년 소득분위별 산과 세부 상병코드별 입원 및 외래 진료 내 역 비교 시의 백분율은 입원과 외래를 구분하여 각 분위수 전체 건 중 해당 세부 상병코드 건이 차지하는 비율로 표시하였다. 또한 2008년 소득분위별 다빈도 질환 비교분석은 임신, 출산 관련 질환의 상병코드 000 (자궁외임신)에서 099 (임신, 출산 및 산욕기에 합병된 기타 산모 질환) 가운데 2008년 기준 상병코드별 입원일수와 외래일수가 각각 가 장 많은 순으로 20 개 상병코드를 선정하였고, 백분율은 각 분위수 전 체 건 중 해당 상병코드 건이 차지하는 비율로 표시하였다. 2008년 주 요 다빈도 질환의 소득분위별 진료실 인원수 비교는 2008년 기준으 로 임신, 출산 관련 질환의 상병코드 가운데 상병코드별 실인원수가 가 장 많은 순으로 20개 상병코드를 선정한 후 해당 상병코드에 대해서 는 1,000 명당 실인원수로 표기하였다. 마지막으로 입원과 외래를 구 분하여 2008년 기준 의료기관종별, 소득분위별 임신, 출산 관련 의료 이용 양상을 비교하였다. 본 연구의 통계분석에는 SAS ver. 9.1 (SAS Institute, Cary, NC, USA)프로그램을 사용하였다.

\section{결 과}

\section{1. 소득분위별 지난 5 년간 산과 진료실적 추이 비교}

2004년부터 2008년까지 5년간 산과 진료실적 추이를 분석한 결 과는 Table 1과 같다. 먼저 소득분위별 입원 진료실적의 경우 소득 1 분위의 입원건수가 지난 5 년간 가장 낮은 비율을 차지하는 가운데 
Table 1. Change in obstetrical care services by income classes

\begin{tabular}{|c|c|c|c|c|c|c|c|}
\hline & & & 2004 & 2005 & 2006 & 2007 & 2008 \\
\hline \multirow[t]{15}{*}{ In-patients } & Income classes & Claims & $87,664(19.0)$ & 81,848 (19.0) & $80,298(18.4)$ & $86,114(18.5)$ & $81,655 \quad(18.7)$ \\
\hline & 1st class & Visit days & $412,705(18.8)$ & $389,769(19.0)$ & $384,995(18.3)$ & 410,705 (18.5) & $391,870(18.7)$ \\
\hline & & Treatment amount & $51,551(18.9)$ & 54,157 (19.0) & $54,785(18.3)$ & $65,341 \quad(18.5)$ & 65,297 (18.6) \\
\hline & 2nd class & Claims & $98,397 \quad(21.3)$ & $87,552(20.4)$ & $84,561 \quad(19.3)$ & $93,882 \quad(20.2)$ & 86,984 (19.9) \\
\hline & & Visit days & $464,325(21.2)$ & $416,362 \quad(20.3)$ & $406,453 \quad(19.4)$ & $444,072(20.0)$ & $414,182(19.8)$ \\
\hline & & Treatment amount & $57,854(21.2)$ & $58,133 \quad(20.4)$ & 57,725 (19.3) & $70,698 \quad(20.0)$ & 69,558 (19.8) \\
\hline & 3rd class & Claims & $89,783(19.4)$ & $79,358 \quad(18.5)$ & $92,584(21.2)$ & 95,790 (20.6) & $90,100 \quad(20.6)$ \\
\hline & & Visit days & $423,914(19.4)$ & $376,882(18.4)$ & $443,372(21.1)$ & $457,378(20.6)$ & 431,132 (20.6) \\
\hline & & Treatment amount & $52,971(19.4)$ & $52,765(18.5)$ & $63,085(21.1)$ & 72,588 (20.6) & $72,392 \quad(20.6)$ \\
\hline & 4th class & Claims & $91,490(19.8)$ & $93,280 \quad(21.7)$ & $93,409(21.4)$ & $96,177 \quad(20.7)$ & $90,391 \quad(20.7)$ \\
\hline & & Visit days & $434,474 \quad(19.8)$ & $444,233 \quad(21.7)$ & $445,826(21.2)$ & $459,274 \quad(20.7)$ & $432,428 \quad(20.7)$ \\
\hline & & Treatment amount & $54,117(19.8)$ & $61,986 \quad(21.7)$ & $63,381 \quad(21.2)$ & 72,906 (20.6) & $72,686 \quad(20.7)$ \\
\hline & 5th class & Claims & 95,202 (20.6) & $87,706 \quad(20.4)$ & 86,643 (19.8) & $93,401 \quad(20.1)$ & $88,162 \quad(20.2)$ \\
\hline & & Visit days & $454,792(20.8)$ & $419,013(20.5)$ & 418,015 (19.9) & $445,101 \quad(20.1)$ & $422,546 \quad(20.2)$ \\
\hline & & Treatment amount & $56,512(20.7)$ & $58,552(20.5)$ & $59,656(20.0)$ & $71,530(20.3)$ & $71,548(20.4)$ \\
\hline \multirow[t]{15}{*}{ Out-patients } & Income classes & Claims & $115,592(20.8)$ & $111,734(20.9)$ & $113,918(20.5)$ & $151,854(20.9)$ & $163,511(20.6)$ \\
\hline & 1st class & Visit days & $195,057(20.7)$ & $187,575(20.7)$ & $191,208(20.3)$ & $208,862(20.2)$ & $209,956(20.0)$ \\
\hline & & Treatment amount & $3,413(21.2)$ & $3,712(21.4)$ & $4,028 \quad(21.0)$ & 4,538 (20.9) & $4,817 \quad(20.8)$ \\
\hline & 2nd class & Claims & $113,428(20.4)$ & 105,192 (19.7) & $104,961 \quad(18.9)$ & 142,893 (19.7) & 155,493 (19.6) \\
\hline & & Visit days & $192,950(20.4)$ & 177,796 (19.7) & 177,375 (18.8) & $200,995(19.5)$ & $203,342(19.4)$ \\
\hline & & Treatment amount & $3,192(19.9)$ & $3,327 \quad(19.2)$ & $3,565(18.6)$ & $4,145(19.1)$ & 4,432 (19.1) \\
\hline & 3rd class & Claims & $103,777(18.7)$ & $93,744 \quad(17.5)$ & $112,327(20.2)$ & $142,836(19.7)$ & $156,244(19.7)$ \\
\hline & & Visit days & $176,351 \quad(18.7)$ & 157,928 (17.5) & 189,505 (20.1) & $203,921 \quad(19.7)$ & 206,412 (19.7) \\
\hline & & Treatment amount & 2,901 (18.1) & $2,956(17.0)$ & $3,741 \quad(19.5)$ & $4,147 \quad(19.1)$ & 4,428 (19.1) \\
\hline & 4th class & Claims & $105,920(19.1)$ & 112,843 (21.1) & $113,911(20.5)$ & $144,295(19.9)$ & $157,806(19.9)$ \\
\hline & & Visit days & $179,798 \quad(19.0)$ & $190,862 \quad(21.1)$ & $193,344 \quad(20.5)$ & $208,405 \quad(20.2)$ & $210,977 \quad(20.1)$ \\
\hline & & Treatment amount & $3,025 \quad(18.8)$ & $3,605 \quad(20.8)$ & $3,877 \quad(20.2)$ & 4,301 (19.8) & 4,587 (19.8) \\
\hline & 5th class & Claims & $116,233 \quad(20.9)$ & $111,252 \quad(20.8)$ & $111,484 \quad(20.0)$ & 143,873 & $159,381 \quad(20.1)$ \\
\hline & & Visit days & $199,706 \quad(21.2)$ & $189,993 \quad(21.0)$ & $191,302 \quad(20.3)$ & $211,021 \quad(20.4)$ & $216,494 \quad(20.7)$ \\
\hline & & Treatment amount & $3,538 \quad(22.0)$ & $3,754 \quad(21.6)$ & $3,975 \quad(20.7)$ & $4,557 \quad(21.0)$ & 4,946 (21.3) \\
\hline
\end{tabular}

Unit, person; day; million won; \%.

2004년의 경우에는 소득2분위(21.3\%), 2008년의 경우에는 소득4분 위(20.7\%)의 입원건수가 가장 높은 비율을 차지하는 것으로 나타났 다. 또한 소득분위별 입원일수와 입원 총 진료비가 차지하는 비율은 입원건수와 유사한 경향을 보이는 것으로 나타났다.

외래 진료실적의 경우에는 입원 진료실적과는 달리 2004년 소득5 분위가 차지하는 외래건수 비율이 20.9\%로 가장 높았으나, 2006년 부터 3년을 종합했을 때 소득1분위의 외래진료건수가 가장 높은 비 율을 차지하는 것으로 나타났다. 한편 외래 총 진료비가 차지하는 비 율은 외래 내원일수가 차지하는 비율과는 달리 소득5분위가 가장 높 은 비율을 차지한 반면 소득3분위가 가장 낮은 비율을 차지하는 것
으로 나타났다

\section{2. 소득분위별 산과 진료 세부코드군별 진료실적 비교}

2008년 1년간 산과 진료실적을 소득분위별로 분석한 결과, 입 원 진료실적은 유산(000-08)의 경우 소득1분위에서 실인원수 기 준으로 $26.3 \%$ 를 차지하여 가장 높은 비율을 차지하는 것으로 나타 났다. 또한 임신, 출산 및 산욕기의 부종, 단백뇨 및 고혈압성 장애 (010-016)도 소득1분위에서 실인원수 기준으로 $22.1 \%$ 를 차지하여 가장 높은 것으로 나타났다. 반면 분만(080-084)의 경우는 소득1분 위에서 $18.0 \%$ 를 차지하여 가장 낮은 것으로 나타났다. 한편 진통 및 
Table 2. Obstetrical care services by income classes and classification of disease categories

\begin{tabular}{|c|c|c|c|c|c|c|c|c|c|c|c|}
\hline \multirow{2}{*}{ In-Patients } & & \multicolumn{2}{|c|}{ 1st class } & \multicolumn{2}{|c|}{2 nd class } & \multicolumn{2}{|c|}{ 3rd class } & \multicolumn{2}{|c|}{ 4th class } & \multicolumn{2}{|c|}{ 5th class } \\
\hline & & & & & & & & & & & \\
\hline \multirow[t]{3}{*}{ 000-008 Abortion } & Patients & 5,042 & (26.3) & 3,737 & (19.5) & 3,264 & (17.0) & 3,424 & $(17.9)$ & 3,680 & (19.2) \\
\hline & Visit days & 20,170 & (27.4) & 14,546 & (19.8) & 12,438 & $(16.9)$ & 12,876 & $(17.5)$ & 13,600 & $(18.5)$ \\
\hline & Treatment amount & 3,950 & $(28.2)$ & 2,776 & (19.8) & 2,328 & (16.6) & 2,417 & $(17.2)$ & 2,546 & $(18.2)$ \\
\hline \multirow{3}{*}{$\begin{array}{l}\text { 010-016 Preeclampsia, } \\
\text { eclampsia }\end{array}$} & Patients & 285 & (22.1) & 251 & (19.5) & 264 & $(20.5)$ & 247 & $(19.2)$ & 242 & $(18.8)$ \\
\hline & Visit days & 1,973 & $(22.2)$ & 1,817 & (20.5) & 1,797 & $(20.2)$ & 1,726 & (19.4) & 1,564 & $(17.6)$ \\
\hline & Treatment amount & 257 & (21.7) & 241 & $(20.3)$ & 244 & (20.6) & 235 & (19.8) & 209 & $(17.6)$ \\
\hline \multirow{3}{*}{$\begin{array}{l}\text { 030-048 Maternal care due } \\
\text { to complications of fetus or } \\
\text { amniotic fluid }\end{array}$} & Patients & 6,271 & $(19.8)$ & 6,266 & (19.8) & 6,539 & (20.7) & 6,277 & $(19.8)$ & 6,305 & (19.9) \\
\hline & Visit days & 42,829 & (18.9) & 43,722 & $(19.2)$ & 46,538 & (20.5) & 46,005 & $(20.2)$ & 48,097 & $(21.2)$ \\
\hline & Treatment amount & 4,225 & (18.9) & 4,335 & (19.4) & 4,635 & (20.8) & 4,486 & (20.1) & 4,635 & (20.8) \\
\hline \multirow{3}{*}{$\begin{array}{l}\text { 060-075 Complications } \\
\text { during the labor and } \\
\text { delivery }\end{array}$} & Patients & 4,388 & (19.6) & 4,657 & (20.8) & 4,676 & (20.9) & 4,517 & $(20.2)$ & 4,133 & (18.5) \\
\hline & Visit days & 25,958 & (18.7) & 28,076 & $(20.2)$ & 29,603 & (21.3) & 29,179 & $(21.0)$ & 26,237 & $(18.9)$ \\
\hline & Treatment amount & 3,752 & $(18.7)$ & 4,050 & $(20.2)$ & 4,240 & $(21.1)$ & 4,213 & $(21.0)$ & 3,804 & $(19.0)$ \\
\hline \multirow[t]{3}{*}{ 080-084 Delivery } & Patients & 59,981 & $(18.0)$ & 66,536 & (19.9) & 69,465 & (20.8) & 69,928 & $(21.0)$ & 67,772 & (20.3) \\
\hline & Visit days & 280,596 & $(18.2)$ & 306,684 & (19.9) & 319,023 & (20.7) & 321,049 & (20.9) & 310,654 & $(20.2)$ \\
\hline & Treatment amount & 51,810 & $(18.0)$ & 56,932 & (19.8) & 59,548 & (20.7) & 59,972 & (20.9) & 58,942 & $(20.5)$ \\
\hline \multirow{3}{*}{$\begin{array}{l}\text { 085-092 Puerperal } \\
\text { complication }\end{array}$} & Patients & 251 & $(18.8)$ & 258 & (19.3) & 296 & (22.1) & 270 & $(20.2)$ & 262 & (19.6) \\
\hline & Visit days & 1,429 & (19.4) & 1,398 & $(19.0)$ & 1,627 & (22.1) & 1,470 & $(20.0)$ & 1,426 & $(19.4)$ \\
\hline & Treatment amount & 160 & $(20.5)$ & 140 & (17.9) & 168 & (21.5) & 149 & (19.1) & 164 & $(21.0)$ \\
\hline \multicolumn{12}{|l|}{ Out-patients } \\
\hline \multirow[t]{3}{*}{ 000-008 Abortion } & Patients & 19,846 & $(25.0)$ & 15,164 & (19.1) & 14,057 & $(17.7)$ & 14,415 & $(18.1)$ & 15,975 & $(20.1)$ \\
\hline & Visit days & 55,776 & (23.7) & 45,069 & (19.1) & 42,426 & $(18.0)$ & 43,931 & (18.7) & 48,315 & $(20.5)$ \\
\hline & Treatment amount & 2,063 & (23.9) & 1,638 & (19.0) & 1,538 & $(17.8)$ & 1,593 & $(18.5)$ & 1,799 & $(20.8)$ \\
\hline \multirow{3}{*}{$\begin{array}{l}\text { 010-016 Preeclampsia, } \\
\text { eclampsia }\end{array}$} & Patients & 1,001 & (20.6) & 1,001 & (20.6) & 1,054 & $(21.7)$ & 975 & (20.1) & 827 & $(17.0)$ \\
\hline & Visit days & 2,062 & (19.9) & 2,040 & (19.7) & 2,373 & (22.9) & 1,988 & $(19.2)$ & 1,890 & (18.3) \\
\hline & Treatment amount & 35 & (19.2) & 35 & (19.2) & 41 & $(22.5)$ & 37 & (20.3) & 34 & $(18.7)$ \\
\hline \multirow{3}{*}{$\begin{array}{l}\text { 030-048 Maternal care due } \\
\text { to complications of fetus or } \\
\text { amniotic fluid }\end{array}$} & Patients & 11,979 & $(18.4)$ & 12,401 & $(19.0)$ & 13,168 & $(20.2)$ & 13,585 & (20.9) & 13,995 & $(21.5)$ \\
\hline & Visit days & 34,422 & $(17.3)$ & 37,011 & (18.6) & 39,681 & $(20.0)$ & 42,427 & (21.4) & 44,986 & $(22.7)$ \\
\hline & Treatment amount & 722 & $(17.6)$ & 757 & (18.5) & 815 & (19.9) & 868 & $(21.2)$ & 940 & (22.9) \\
\hline \multirow{3}{*}{$\begin{array}{l}\text { 060-075 Complications } \\
\text { during the labor and } \\
\text { delivery }\end{array}$} & Patients & 1,880 & $(19.0)$ & 1,960 & (19.8) & 2,032 & (20.5) & 2,119 & (21.4) & 1,918 & (19.4) \\
\hline & Visit days & 2,961 & $(18.4)$ & 3,084 & $(19.2)$ & 3,306 & (20.6) & 3,530 & (22.0) & 3,173 & (19.8) \\
\hline & Treatment amount & 57 & $(18.6)$ & 60 & (19.5) & 65 & $(21.2)$ & 65 & $(21.2)$ & 60 & (19.5) \\
\hline \multirow[t]{3}{*}{ 080-084 Delivery } & Patients & 2,784 & $(16.5)$ & 3,071 & $(18.2)$ & 3,256 & (19.3) & 3,586 & $(21.2)$ & 4,192 & $(24.8)$ \\
\hline & Visit days & 4,696 & $(16.0)$ & 5,369 & (18.3) & 5,642 & $(19.2)$ & 6,247 & (21.3) & 7,437 & $(25.3)$ \\
\hline & Treatment amount & 121 & $(15.5)$ & 141 & $(18.1)$ & 146 & $(18.7)$ & 166 & (21.3) & 205 & $(26.3)$ \\
\hline \multirow{3}{*}{$\begin{array}{l}\text { 085-092 Puerperal } \\
\text { complication }\end{array}$} & Patients & 15,178 & $(18.2)$ & 16,498 & (19.8) & 17,371 & (20.9) & 17,170 & (20.6) & 17,086 & $(20.5)$ \\
\hline & Visit days & 26,036 & $(18.1)$ & 28,197 & (19.6) & 29,916 & (20.8) & 29,980 & $(20.8)$ & 29,722 & (20.7) \\
\hline & Treatment amount & 325 & (18.1) & 342 & (19.1) & 366 & (20.4) & 372 & (20.8) & 386 & (21.6) \\
\hline
\end{tabular}

Unit, person; day; million won; \%. 
KJOG Vol. 55, No. 11, 2012

Table 3. Obstetrical care service compared by the income classes and the patient characteristics

\begin{tabular}{|c|c|c|c|c|c|c|c|c|c|c|c|c|c|c|}
\hline & & & \multicolumn{2}{|c|}{ Patients } & \multicolumn{2}{|c|}{ 1st class } & \multicolumn{2}{|c|}{ 2nd class } & \multicolumn{2}{|c|}{ 3rd class } & \multicolumn{2}{|c|}{ 4th class } & \multicolumn{2}{|c|}{ 5th class } \\
\hline & & & In & Out & In & Out & In & Out & In & Out & In & Out & In & Out \\
\hline \multirow{7}{*}{$\begin{array}{l}000-008 \\
\text { Abortion }\end{array}$} & Age & $<34$ & 17,310 & 71,486 & 26.4 & 24.9 & 19.9 & 19.4 & 17.6 & 18.2 & 17.9 & 18.5 & 18.2 & 19.1 \\
\hline & & $\geq 35$ & 1,837 & 7,971 & 25.6 & 26.0 & 15.8 & 16.3 & 12.2 & 13.5 & 17.7 & 15.2 & 28.7 & 29.1 \\
\hline & Resident area & Big city & 8,587 & 36,721 & 25.2 & 24.2 & 19.5 & 19.0 & 17.0 & 17.5 & 18.2 & 18.3 & 20.1 & 21.0 \\
\hline & & Small city & 8,999 & 37,270 & 26.4 & 24.7 & 19.2 & 19.0 & 17.3 & 18.1 & 18.0 & 18.4 & 19.2 & 19.9 \\
\hline & & Rural & 1,562 & 5,686 & 32.0 & 31.8 & 21.5 & 20.0 & 16.1 & 16.4 & 15.7 & 16.1 & 14.7 & 15.8 \\
\hline & Type of insurance & Industrial work & 11,595 & 50,767 & 25.6 & 24.8 & 19.2 & 19.0 & 17.3 & 17.6 & 18.1 & 18.1 & 19.9 & 20.5 \\
\hline & & Self-employee & 7,555 & 28,709 & 27.4 & 25.4 & 20.1 & 19.2 & 16.7 & 17.8 & 17.6 & 18.2 & 18.2 & 19.5 \\
\hline \multirow{7}{*}{$\begin{array}{l}\text { 010-016 } \\
\text { Preeclampsia, } \\
\text { eclampsia }\end{array}$} & Age & $<34$ & 1,223 & 4,637 & 21.6 & 20.5 & 19.8 & 20.9 & 20.8 & 22.0 & 19.3 & 20.1 & 18.6 & 16.6 \\
\hline & & $\geq 35$ & 66 & 221 & 31.8 & 23.5 & 13.6 & 14.9 & 15.2 & 16.3 & 16.7 & 18.6 & 22.7 & 26.7 \\
\hline & Resident area & Big city & 585 & 1,749 & 21.4 & 20.8 & 20.7 & 20.3 & 19.8 & 21.1 & 19.8 & 18.9 & 18.3 & 18.9 \\
\hline & & Small city & 573 & 2,747 & 21.5 & 20.0 & 18.2 & 20.7 & 20.8 & 22.2 & 19.9 & 20.6 & 19.7 & 16.5 \\
\hline & & Rural & 130 & 378 & 28.5 & 23.8 & 20.0 & 21.4 & 22.3 & 20.9 & 12.3 & 21.7 & 16.9 & 12.2 \\
\hline & Insurance & Industrial work & 842 & 3,285 & 22.0 & 20.1 & 17.8 & 20.7 & 20.7 & 22.3 & 20.1 & 20.5 & 19.5 & 16.4 \\
\hline & & Self-employee & 447 & 1,573 & 22.4 & 21.7 & 22.6 & 20.5 & 20.1 & 20.5 & 17.4 & 19.1 & 17.4 & 18.2 \\
\hline \multirow{7}{*}{$\begin{array}{l}\text { 030-048 } \\
\text { Maternal } \\
\text { care due to } \\
\text { complications } \\
\text { of fetus or } \\
\text { amniotic fluid }\end{array}$} & Age & $<34$ & 30,904 & 63,432 & 19.8 & 18.3 & 19.9 & 19.1 & 20.8 & 20.3 & 19.9 & 20.9 & 19.7 & 21.2 \\
\hline & & $\geq 35$ & 754 & 1,696 & 20.2 & 20.9 & 16.2 & 15.0 & 16.2 & 15.7 & 17.1 & 17.6 & 30.4 & 30.7 \\
\hline & Resident area & Big city & 14,933 & 25,655 & 19.3 & 18.2 & 19.9 & 19.5 & 20.4 & 19.7 & 19.8 & 20.8 & 20.7 & 21.8 \\
\hline & & Small city & 14,132 & 36,075 & 19.3 & 17.6 & 19.7 & 18.5 & 20.9 & 20.7 & 20.1 & 21.2 & 19.9 & 22.0 \\
\hline & & Rural & 2,611 & 3,942 & 25.5 & 26.1 & 19.6 & 20.8 & 20.7 & 19.3 & 18.5 & 18.2 & 15.7 & 15.6 \\
\hline & Insurance & Industrial work & 21,716 & 46,265 & 20.1 & 18.7 & 19.6 & 19.0 & 20.5 & 20.1 & 19.7 & 21.1 & 20.1 & 21.1 \\
\hline & & Self-employee & 9,947 & 18,932 & 19.2 & 17.7 & 20.2 & 19.1 & 20.9 & 20.4 & 20.2 & 20.3 & 19.5 & 22.4 \\
\hline \multirow{7}{*}{$\begin{array}{l}\text { 060-075 } \\
\text { Complications } \\
\text { during the } \\
\text { labor and } \\
\text { delivery }\end{array}$} & Age & $<34$ & 21,967 & 9,605 & 19.6 & 18.9 & 20.9 & 19.8 & 21.1 & 20.8 & 20.2 & 21.5 & 18.3 & 19.1 \\
\hline & & $\geq 35$ & 404 & 304 & 21.3 & 22.7 & 18.8 & 19.7 & 12.6 & 12.5 & 20.0 & 19.1 & 27.2 & 26.0 \\
\hline & Resident area & Big city & 11,815 & 4,299 & 18.6 & 17.8 & 20.9 & 19.4 & 21.0 & 20.9 & 20.6 & 21.0 & 18.9 & 20.8 \\
\hline & & Small city & 8,821 & 4,670 & 19.7 & 18.4 & 20.5 & 19.8 & 20.8 & 20.3 & 20.4 & 22.2 & 18.6 & 19.2 \\
\hline & & Rural & 1,739 & 952 & 26.3 & 26.6 & 21.7 & 21.0 & 20.8 & 19.4 & 16.1 & 19.0 & 15.0 & 14.0 \\
\hline & Insurance & Industrial work & 15,470 & 6,811 & 20.0 & 19.2 & 20.6 & 19.3 & 21.1 & 20.7 & 20.3 & 21.7 & 18.0 & 19.1 \\
\hline & & Self-employee & 6,902 & 3,100 & 18.7 & 18.6 & 21.3 & 20.9 & 20.5 & 20.0 & 20.0 & 20.7 & 19.5 & 19.8 \\
\hline \multirow{7}{*}{$\begin{array}{c}\text { 080-084 } \\
\text { Delivery }\end{array}$} & Age & $<34$ & 327,609 & 16,205 & 17.9 & 16.4 & 20.0 & 18.3 & 20.9 & 19.5 & 21.0 & 21.3 & 20.1 & 24.5 \\
\hline & & $\geq 35$ & 6,073 & 684 & 20.4 & 18.3 & 16.5 & 14.8 & 15.7 & 14.3 & 17.9 & 19.9 & 29.4 & 32.7 \\
\hline & Resident area & Big city & 153,032 & 7,554 & 17.4 & 15.8 & 20.0 & 17.7 & 20.5 & 18.4 & 21.1 & 21.4 & 21.1 & 26.6 \\
\hline & & Small city & 158,784 & 8,406 & 17.7 & 16.3 & 19.7 & 18.4 & 21.2 & 20.0 & 21.2 & 21.3 & 20.3 & 24.1 \\
\hline & & Rural & 21,728 & 944 & 24.5 & 24.4 & 21.7 & 20.2 & 20.4 & 19.7 & 18.4 & 19.0 & 15.0 & 16.7 \\
\hline & Insurance & Industrial work & 234,920 & 11,757 & 18.3 & 16.7 & 19.6 & 17.3 & 20.7 & 19.1 & 21.0 & 21.5 & 20.3 & 25.4 \\
\hline & & Self-employee & 98,764 & 5,133 & 17.2 & 16.0 & 20.7 & 20.2 & 21.1 & 19.8 & 20.8 & 20.7 & 20.3 & 23.4 \\
\hline \multirow{7}{*}{$\begin{array}{l}\text { 085-092 } \\
\text { Puerperal } \\
\text { complication }\end{array}$} & Age & $<34$ & 1,299 & 80,849 & 18.5 & 18.0 & 19.4 & 19.9 & 22.3 & 21.0 & 20.3 & 20.7 & 19.5 & 20.3 \\
\hline & & $\geq 35$ & 38 & 2,454 & 28.9 & 24.8 & 15.8 & 15.3 & 15.8 & 14.4 & 15.8 & 16.4 & 23.7 & 29.1 \\
\hline & Resident area & Big city & 619 & 36,739 & 17.9 & 17.8 & 17.1 & 19.8 & 23.6 & 20.6 & 19.2 & 20.8 & 22.1 & 21.0 \\
\hline & & Small city & 619 & 40,804 & 17.1 & 17.7 & 21.6 & 19.6 & 20.8 & 21.1 & 21.8 & 20.8 & 18.6 & 20.9 \\
\hline & & Rural & 98 & 5,904 & 34.7 & 24.7 & 18.4 & 20.9 & 20.4 & 21.1 & 16.3 & 18.3 & 10.2 & 15.0 \\
\hline & Insurance & Industrial work & 920 & 58,265 & 19.2 & 18.7 & 19.8 & 19.5 & 22.2 & 20.7 & 19.3 & 20.5 & 19.5 & 20.7 \\
\hline & & Self-employee & 417 & 25,058 & 17.7 & 17.2 & 18.2 & 20.6 & 22.1 & 21.3 & 22.1 & 20.7 & 19.9 & 20.1 \\
\hline
\end{tabular}

Unit, Person, \%; In, in-patients; Out, out-patients. 
분만합병증(060-075)의 경우는 소득5분위에서 $18.5 \%$ 를 차지하여 가장 낮게 나타났으며, 태아와 양막강 및 가능한 분만문제와 관련된 산모관리(030-039)에서는 소득계층별 차이가 크지 않은 것으로 나 타났다.

외래 진료실적의 경우도 입원 진료실적과 마찬가지로 유산 (000-08)은 소득1분위에서 실인원수 기준으로 $25.0 \%$ 를 차지하여 가 장 높은 비율을 차지하는 것으로 나타났고 분만(080-084)의 경우 $16.5 \%$ 로 가장 낮은 것으로 나타났다(Table 2).

\section{3. 소득분위별 대상자 특성에 따른 진료실적 비교}

산과 진료세부코드군별 진료실적을 대상자의 일반적 특성별로 구분 하여 분석한 결과는 Table 3 과 같다. 유산과 관련된 입원 진료실적의 경우 연령군별로는 34 세 미만군의 경우에는 소득 1 분위가 $26.4 \%$ 로 가 장 많았고, 35 세 이상 연령군에서는 소득5분위가 $28.7 \%$ 로 가장 많게 나타났다. 거주지별로 분석한 결과 소득1분위군 내에서는 특히 읍면 거주자가 $32.0 \%$ 로 가장 높은 비율을 차지하는 반면 소득5분위군 내에 서는 대도시 거주자가 $20.1 \%$ 로 가장 높은 비율을 차지하여 다른 양상 을 보이는 것으로 나타났다. 직역별로도 소득1분위와 2 분위에서는 상 대적으로 지역가입자가 직장가입자보다 높은 비율을 차지하는 것으로 나타났다. 즉 유산의 경우 소득이 낮은 소득 1 분위에서는 읍면에 거주 하는 지역가입자가 고위험군이며, 소득5분위에서는 대도시에 거주하 는 고령 임신부가 고위험군으로 나타났다. 또한 유산 이외의 산과적 문 제에 있어서, 소득1분위에서는 읍면에 거주하는 자가, 소득5분위에서 는 35 세 고령 임신부가 타 집단에 비해 진료실적이 많은 고위험군으로 나타났다.

\section{4. 소득분위별 다빈도 질환 비교}

대상자의 입원 및 외래 방문일수를 기준으로 산과 진료 다빈도 질환 을 추출한 후 소득분위별 1,000 명당 진료실인원수를 비교분석한 결 과는 Table 4 와 같다. 입원진료의 경우 분만 즉 단일자연분만, 제왕절 개, 겸자분만, 보조단일분만이 주요 다빈도 질환을 차지하고 있는 것 으로 나타났다. 소득계층별로 차이를 보이는 주요 질환을 살펴보면 소 득 1 분위에서 단일자연분만이 1,000 명당 423.9 명으로 가장 적은 것으 로 나타났고, 겸자 및 흡입 분만(51.0명), 자궁외임신(32.7명), 모성골반 이상으로 인한 난산(6.8명)은 소득1분위에서 가장 많은 것으로 나타났 다. 한편 소득5분위에서는 다태분만(10.0명)이 가장 많은 것으로 나타 났다.

외래 진료의 경우는 유산, 초기 임신 중 출혈, 산욕기 감염, 유방감염, 임신성 당뇨병 등이 주요 다빈도 질환으로 나타났다. 소득계층별로는 소득1분위에서 초기 임신 중 출혈(138.2명), 자궁외임신(53.4명), 자연 유산(42.2명) 등 산과적 문제가 다른 소득계층에 비해 많은 것으로 나 타났다. 한편 소득5분위에서는 유방감염(61.4명), 유방 및 수유의 기타 장애(56.5명), 임신성 당뇨병(56.8명), 제왕절개(55.7명) 등 분만 및 산 욕기의 합병증이 다른 계층에 비해 많은 것으로 나타났다.

\section{5. 소득분위별 의료기관 이용양상 비교}

산과 진료에 관련된 의료기관종별의 이용양상을 비교한 결과, 입원 진료의 경우 소득수준이 높아질수록 대형 병원에서 진료를 받고 있는 것으로 나타났다. 즉 소득1분위에서는 종합병원급 입원 실원수가 차지 하는 비율이 $16.5 \%$ 인데 비해 소득5분위에서는 $24.6 \%$ 나 되는 것으로 나타났다. 병원급에서는 소득분위별 입원실 인원수가 차지하는 비율의 차이가 종합병원급 보다는 적었지만 여전히 소득1분위의 비율이 낮은 것으로 나타났다.

외래의 경우는 입원보다 종합병원급 이용률의 차이가 소득군별로 더 욱 크게 벌어져 소득1분위의 외래일수가 차지하는 비율이 $16.5 \%$ 이지 만 소득5분위에서는 $26.1 \%$ 를 차지하는 것으로 나타났다. 의원급 외래 이용은 입원과는 역방향으로 소득1분위 $21.3 \%$, 소득5분위 $18.1 \%$ 로 소득수준이 낮을수록 의원급 이용률이 높은 것으로 나타났다(Table 5).

\section{고 찰}

본 연구는, 임신부의 연령, 소득, 거주지 등 대상자별 특성을 고려하 지 않고 일괄적으로 적용하고 있는 그 간의 저출산 정책에 대해 보다 실효성 있는 대책 마련을 위한 일환으로, 임신부의 소득계층별 임신, 출산 관련 의료 이용양상을 비교하여 고위험군을 세분화함으로써 궁극 적으로는 저출산 극복을 위한 정책 대안의 기초자료를 제공하고자 시 도되었다.

우리나라의 저출산 대책 수립배경은 세계 최저수준의 출산율과 그에 따른 인구의 고령화이다. 한국의 합계출산율은 2005년 1.08로 최저 수 치를 기록한 이래 2011년 1.24로 여전히 낮은 수준에 머물러 있으며 [1], 이에 정부는 2000년대 들어 출산과 양육에 유리한 환경 조성을 위 해 출산장려 정책들을 제시하였고, 최근에는 임신, 출산의 사회적 책임 을 강조함에 따라 사회 시스템을 변화시켜 출산과 양육에 유리한 환경 을 조성하는데 목표를 두고 관련 정책을 내놓고 있다[11]. 이러한 관점 에서 볼 때 우리나라 의료보장의 주축을 이루고 있는 건강보험제도를 통해 임신부의 경제적 부담을 덜고 건강한 태아를 분만할 수 있는 출산 환경을 조성하기 위한 임신, 출산 관련 정책의 시행은 매우 중요하다. 특히 외환위기 이후 경제사정이 어려워지면서 출산에 영향을 미치는 중요한 요인으로 가구소득수준이 지적되고 있으며[12,13], 실제 저소 득층 여성의 경우 사회의 다양한 혜택에도 불구하고 산전진찰을 덜 받 고 있는 것으로 조사되었다[7]. 이는 분만 전후의 유병률 증가로 이어 질 수 있으므로, 소득수준에 따른 산과진료 실적에 대한 분석이 필요한 시점이다.

본 연구분석 결과, 소득1분위에서 입원건수와 총 입원 진료비 모두 가장 낮은 비율을 차지하는 반면, 외래진료의 경우 특히 조사기준시기 최근 3년간의 실적을 분석한 결과 총 진료건수는 소득1분위가 가장 높 은 것으로 나타났고 총 진료비는 소득1분위와 5 분위에서 비슷한 수준 으로 높은 것으로 나타났다. 이처럼 입원진료와 외래진료 실적이 상반 된 결과는, 분석 결과를 종합해 볼 때 다음과 같이 해석할 수 있을 것이 
Table 4. Number of patients of frequency diseases by the income classes

\begin{tabular}{|c|c|c|c|c|c|c|c|}
\hline & & & 1st class & 2nd class & 3rd class & 4th class & 5th class \\
\hline \multirow[t]{13}{*}{ In-Patients } & 080 & Vaginal delivery in singleton pregnancy & 423.9 & 451.5 & 457.2 & 466.1 & 466.0 \\
\hline & 082 & Single delivery by Cesarean section & 293.9 & 296.1 & 296.4 & 293.2 & 292.8 \\
\hline & 081 & Delivery with forceps or vacuum extraction & 51.0 & 49.2 & 48.5 & 43.9 & 39.9 \\
\hline & 020 & Threatened abortion & 22.2 & 19.7 & 19.9 & 21.2 & 21.6 \\
\hline & 000 & Ectopic pregnancy & 32.7 & 20.2 & 16.1 & 15.7 & 17.8 \\
\hline & 060 & Preterm labor & 16.3 & 16.1 & 16.3 & 17.2 & 16.9 \\
\hline & 042 & Premature rupture of amniotic membrane & 13.3 & 13.6 & 13.3 & 11.6 & 10.9 \\
\hline & 063 & Prolonged labor & 12.3 & 12.9 & 12.8 & 12.3 & 11.3 \\
\hline & 021 & Hyperemesis gravidarum & 10.0 & 8.9 & 9.3 & 9.0 & 9.3 \\
\hline & 084 & Multiple labor & 5.7 & 6.0 & 6.7 & 8.8 & 10.0 \\
\hline & 065 & Dystocia due to cephalopelvic disproportion & 6.8 & 5.6 & 5.2 & 4.6 & 3.8 \\
\hline & 033 & Maternal care for known of suspected disproportion & 5.6 & 5.6 & 4.9 & 4.2 & 4.1 \\
\hline & 061 & Failed induction of labor & 5.2 & 5.2 & 4.4 & 4.0 & 3.9 \\
\hline \multirow[t]{12}{*}{ Out-patients } & 020 & Threatened abortion & 154.9 & 140.5 & 132.2 & 133.0 & 128.8 \\
\hline & 086 & Puerperal infection & 92.4 & 109.8 & 112.0 & 104.6 & 98.3 \\
\hline & 091 & Infection of breast associated with childbirth & 45.1 & 54.6 & 59.4 & 63.1 & 61.4 \\
\hline & 092 & $\begin{array}{l}\text { Other disorders of breast associated with childbirth } \\
\text { or lactation }\end{array}$ & 48.0 & 49.8 & 54.5 & 53.9 & 56.5 \\
\hline & 024 & Diabetes mellitus in pregnancy & 41.6 & 49.6 & 54.3 & 55.0 & 56.8 \\
\hline & 021 & Hyperemesis gravidarum & 51.9 & 51.1 & 52.3 & 49.8 & 49.8 \\
\hline & 034 & $\begin{array}{l}\text { Maternal care for known or suspected abnormalities } \\
\text { of pelvic organs }\end{array}$ & 37.9 & 40.5 & 44.1 & 49.7 & 53.4 \\
\hline & 082 & Single delivery by Cesarean section & 35.4 & 41.7 & 44.2 & 48.4 & 55.7 \\
\hline & 023 & Genitourinary tract infection in pregnancy & 42.7 & 43.5 & 41.7 & 40.9 & 38.5 \\
\hline & 000 & Ectopic pregnancy & 53.4 & 39.8 & 33.4 & 33.5 & 35.5 \\
\hline & 003 & Spontaneous abortion & 42.2 & 33.5 & 30.1 & 31.2 & 32.2 \\
\hline & 072 & Postpartum bleedin & 9.4 & 11.8 & 12.8 & 13.1 & 12.5 \\
\hline
\end{tabular}

Unit, persons per 1,000.

Table 5. Obstetrical care services utilizations by income classes and medical institutions

\begin{tabular}{|c|c|c|c|c|c|c|c|c|c|c|c|c|}
\hline \multirow[b]{2}{*}{ In-patients } & \multirow[b]{2}{*}{ General hospital } & \multirow[b]{2}{*}{ Patients } & \multicolumn{2}{|c|}{ 1st class } & \multicolumn{2}{|c|}{ 2nd class } & \multicolumn{2}{|c|}{ 3rd class } & \multicolumn{2}{|c|}{ 4th class } & \multicolumn{2}{|c|}{ 5th class } \\
\hline & & & 11,808 & (16.5) & 12,588 & (17.5) & 14,109 & $(19.7)$ & 15,573 & $(21.7)$ & 17,685 & $(24.6)$ \\
\hline & & Visit days & 83,356 & (16.7) & 87,528 & (17.5) & 99,144 & $(19.8)$ & 109,222 & (21.9) & 120,538 & $(24.1)$ \\
\hline & Hospital & Patients & 24,660 & $(17.6)$ & 27,452 & (19.6) & 29,247 & (20.9) & 29,880 & $(21.3)$ & 28,927 & (20.6) \\
\hline & & Visit days & 124,704 & (17.8) & 137,496 & (19.6) & 146,794 & $(21.0)$ & 147,813 & $(21.1)$ & 143,280 & $(20.5)$ \\
\hline & Clinic & Patients & 33,804 & (19.7) & 36,652 & (21.3) & 36,516 & $(21.3)$ & 34,288 & $(20.0)$ & 30,536 & $(17.8)$ \\
\hline & & Visit days & 163,183 & $(20.0)$ & 174,103 & $(21.3)$ & 172,286 & $(21.1)$ & 161,866 & (19.8) & 144,624 & $(17.7)$ \\
\hline \multirow[t]{6}{*}{ Out-patients } & General hospital & Patients & 8,713 & (16.5) & 9,177 & (17.3) & 10,300 & (19.5) & 11,278 & $(21.3)$ & 13,449 & $(25.4)$ \\
\hline & & Visit days & 22,922 & (15.6) & 25,396 & (17.3) & 28,262 & (19.3) & 31,803 & $(21.7)$ & 38,238 & (26.1) \\
\hline & Hospital & Patients & 17,106 & (18.5) & 18,011 & (19.5) & 18,794 & $(20.3)$ & 19,367 & $(21.0)$ & 19,098 & $(20.7)$ \\
\hline & & Visit days & 53,796 & (17.9) & 57,810 & $(19.2)$ & 61,512 & (20.5) & 63,379 & $(21.1)$ & 64,240 & (21.4) \\
\hline & Clinic & Patients & 33,222 & $(21.4)$ & 31,818 & (20.5) & 31,343 & $(20.1)$ & 30,341 & (19.5) & 28,854 & (18.5) \\
\hline & & Visit days & 77,250 & $(21.3)$ & 74,888 & (20.6) & 74,029 & $(20.4)$ & 71,682 & (19.7) & 65,631 & (18.1) \\
\hline
\end{tabular}

Unit, Person; Day; \%. 


\section{KOREAN JOURNAL OF OBSTETRICS \& GYNECOLOGY}

Kyung $\mathrm{Ha} \mathrm{Kim,} \mathrm{et} \mathrm{al.} \mathrm{Obstetric} \mathrm{services} \mathrm{by} \mathrm{income} \mathrm{classes}$

다. 우선, 소득 1 분위 집단의 입원 진료실적이 적은 것은, 저소득층 임신 부의 경제적 문제뿐 아니라 저학력, 낮은 임금, 장시간의 노동 및 임신 부를 위한 직장에서의 제한된 복지제도와 같은 요인이 의료서비스이용 장애요인으로 작용한다는 일부 보고서[9,14]와 유사한 맥락으로 해석 할 수 있을 것이다. 저소득 임신부의 외래 진료실적과 진료비의 상대적 인 증가는 저소득층 여성의 의료이용 접근성 향상과 소득계층 간 의료 이용의 격차의 감소 측면에서 긍정적으로 평가할 수 있지만, 저소득층 임신부의 의료비 증가는 총 가구수입 대비 의료비 비중 증가와 연결되 어 가계부담으로 직결될 수 있다는 문제점을 고려할 때, 저소득층 임신 부 대상의 경제적 지원 강화가 필요할 것으로 생각된다.

다음으로 소득분위별 산과 진료실적을 비교한 결과를 살펴보면, 입 원 진료실적의 경우 소득1분위에서 유산(00-08)과 전자간증, 자간증 (010-016)의 비율이 가장 높은 것으로 나타난 반면, 분만(080-084) 이 가장 낮은 비율을 보이는 것으로 나타났다. 외래 진료실적에서도 유 산(000-08)의 경우 소득1분위의 비율이 가장 높게 나타났다. 대상자 의 일반적 특성별로 구분하여 분석한 결과에서는, 유산의 경우 소득1 분위에서는 연령대별로 큰 차이가 없이 유산 비율이 높게 확인되고, 읍 면에 거주하는 지역가입자가 고위험군이며, 소득5분위에서는 대도시 에 거주하는 35 세 이상의 직장가입자가 고위험군인 것으로 나타났다. 이런 결과를 종합해보면, 고령 임신 자체는 소득수준과는 상관없이, 유 산의 주요증가 원인임을 확인해준다[15]. 또한 저소득 계층 여성의 경 우 사회경제적인 요인에 의한 유산이 주된 산과적 문제로 부각됨으로 써 향후 저소득층 여성을 대상으로 위생학적, 영양학적 측면 등을 포괄 적으로 고려한 유산 관련 요인을 심층적으로 분석할 필요가 있겠다. 또 한 저소득층 여성은 전자간증, 자간증 등(010-016)의 비율이 높게 나 타났는데 이는 기존보고[16,17]와 유사한 결과로서, 임상적으로는 저 소득 임신부에서 임신 중 고혈압성 질환에 대한 각별한 주의를 필요로 함을 시사한다. 더불어 저소득층 여성의 낮은 분만율은, 출산, 양육이 저소득 계층 여성들에게 또 다른 경제적 부담이 될 수 있다는 선행연구 $[12,18]$ 와 동일한 맥락으로 해석될 수 있으며 분만율 증가를 위해서라 도 취약계층에 대한 의료지원 확대는 필요할 것으로 판단된다. 한편 소 득5분위 임신부는, 입원의 경우 다태분만이 많은 것으로 나타났고, 외 래의 경우는 유방감염, 유방 및 수유의 기타장애, 임신성 당뇨병, 제왕 절개 등 분만 및 산욕기의 합병증이 다른 계층에 비해 많은 것으로 나 타났는데 이는 임신부의 고령화에 기인하는 것으로 보여지며, 향후 고 령 임신부를 위한 산전관리방안 프로그램 개발이 필요할 것으로 생각 된다.

마지막으로 소득분위별 의료기관 이용양상을 비교한 결과, 소득수준 이 높아질수록 대형병원에서의 입원 및 외래 이용률이 높은 것으로 나 타났으며, 특히 외래 진료의 경우 종합병원급 이용률의 차이가 소득분 위별로 더욱 컸던 것으로 나타났다. 이러한 결과는 저소득층 여성들은 타 의료기관에 비해 1차 의료기관을 더 빈번히 이용하며, 종합병원 이 용률에 소득수준이 주요 변수라는 연구결과와 일치한다[14,19]. 앞서 확인되었듯 저소득층 여성의 경우 초기 임신성 출혈, 자연유산 및 자궁 외임신 등 산과적 건강문제 발생위험이 높은 고위험 임신부로 분류될
수 있고, 저소득층 여성의 의료이용 접근성 장애는 모성사망률과 영아 사망률에 부정적 영향을 끼칠 수 있다는 선행연구[8,9]를 고려할 때 향 후 이들 저소득층 여성을 대상으로 산과 관련 의료비 및 의료이용실태 를 보다 체계적으로 분석하여 이들 대상의 형평성 확보 방안 모색이 시 급하리라 생각된다.

이상의 연구는 첫째, 전국 건강보험가입자를 대상으로 건강보험공단 에 청구된 자료만을 활용함으로써 건강보험 비급여 항목과 관련된 산 과 진료실적은 포함하지 못한 한계가 있고 둘째, 직장 여성의 경우 배 우자의 소득을 제외한 여성 자신의 소득만이 고려되었다는 한계점이 있으며 셋째, 지역가입자와 직장가입자의 이원화된 건강보험료 부과기 준에 따른 소득계층을 분류하였다는 한계점이 있다.

그럼에도 불구하고 본 연구는 최근 5 년간 건강보험가입자 전수를 대 상으로 소득분위별 산과 진료실적을 분석하여 소득계층별로 다빈도 질 환과 의료이용양상의 격차를 확인할 수 있었다. 즉, 저소득층의 높은 초기 임신성 출혈, 높은 자연유산율과 자궁외임신율, 낮은 출산율 및 고소득 여성의 높은 고령임신, 다태임신 등 소득계층별 산과적 주요 건 강문제를 확인할 수 있었으며, 이와 더불어 저소득층의 가계 소득 대비 높은 의료비 부담과 종합병원이용 접근성 장애 등을 확인할 수 있었다. 향후 소득계층별 다빈도 산과 질환에 대한 맞춤형 산전관리 프로그램 마련과 지원 정책 확립이 필요할 것이다.

\section{References}

1. Stastics Korea. Birth stastics 2010 [Internet]. Daejeon: Korea National Statistical Office; 2012 [cited 2012 May 1]. Avilable from: http://www.index.go.kr/egams/stts/jsp/potal/stts/PO_ STTS_IdxMain.jsp?idx_cd=1428.

2. Kim KH, Hwang RI, Yoon JW, Kim JS. Prenatal care utilization and expenditure among pregnant women. Korean J Health Policy Adm 2009; 19:53-65.

3. Song YW, Shin JH, Yoon YS, Jeong HC, Yim HE, Choi BM, et al. Preinatal complication of mothers and neonates resulting from inadequate prenatal care. Korean J Perinatol 2010;21:347-55.

4. Huh SI. Changes in the financial burden of health expenditures by income level. Health Welf Policy Forum 2009;149:4862.

5. Hwang RI, Lee HY, Kim JH. The comparative analysis for outpatients service utilization by income level among children under 6 years. Seoul: Health Insurance Forum; 2007. p.110-28.

6. Park JE, Lee HJ. Study on maternal health care and social support for low income women. Korea Womens Dev Inst 2000;58:173-87.

7. Heaman MI, Green CG, Newburn-Cook CV, Elliott LJ, Helewa ME. Social inequalities in use of prenatal care in Manitoba. J 
Obstet Gynaecol Can 2007;29:806-16.

8. Dhar RS, Nagpal J, Sinha S, Bhargava VL, Sachdeva A, Bhartia A. Direct cost of maternity-care services in South Delhi: a community survey. J Health Popul Nutr 2009;27:368-78.

9. Skordis-Worrall J, Pace N, Bapat U, Das S, More NS, Joshi W, et al. Maternal and neonatal health expenditure in Mumbai slums (India): a cross sectional study. BMC Public Health 2011;11:150.

10. Storeng KT, Baggaley RF, Ganaba R, Ouattara F, Akoum MS, Filippi V. Paying the price: the cost and consequences of emergency obstetric care in Burkina Faso. Soc Sci Med 2008;66:545-57.

11. Hwang NM. Future directions of maternal and child health policy for healthy start in life. Health Welf Policy Forum 2008;141:5-19.

12. Jung $H E$, Jin MR. The intention of having a second child by the employment status of married women. Korea J Popul Stud 2008;31:151-68.

13. Shin Y. An analysis of the effect of burden of childcare and education on childbirth. Health Soc Sci 2008;28:103-34.
14. Weitzman BC, Berry CA. Health status and health care utilization among New York City home attendants: an illustration of the needs of working poor, immigrant women. Women Health 1992;19:87-105.

15. Kim TE, Lee SP, Park JM, Whang BC, Kim SY. The effects of maternal age on outcome of pregnancy in healthy elderly primipara. Korean J Perinatol 2009;20:146-52.

16. Bener A, Saleh NM, Al-Hamaq A. Prevalence of gestational diabetes and associated maternal and neonatal complications in a fast-developing community: global comparisons. Int J Womens Health 2011;3:367-73.

17. Duley L. The global impact of pre-eclampsia and eclampsia. Semin Perinatol 2009;33:130-7.

18. Song DY. Mental health service utilization and social support for low-income pregnant and postpartum women: a case study on medicaid mothers in America. Korean J Womens Health 2001;2:121-49.

19. Kim JS. A sociological analysis of the utilization behavior of general hospital in an urban community. Ewha J Soc Sci 2000;4:59-83. 


\section{전국 건강보험가입자의 소득계층별 산과 의료서비스 이용 실적 비교분석}

${ }^{1}$ 근로복지공단, ${ }^{2}$ 수원여자대학교 간호학과, ${ }^{3}$ 고려대학교 안암병원 산부인과

김경하 ${ }^{1}$, 황라일 ${ }^{2}$, 윤지원 ${ }^{2}$, 류기진 ${ }^{3}$, 홍순철 ${ }^{3}$

목적

본 연구는 소득계층별 산과 진료실적 추이, 주요 다빈도 질환 및 의료기관 이용양상을 비교분석하기 위해 시도하였다.

연구방법

2004-2008년 지난 5년간 건강보험청구자료 중 산과코드(000-099) 전체를 발췌하여 분석하였다. 대상자의 건강보험 자격자료를 이용 해 대상자의 일반적 특성을 구분하였고, 건강보험료 부과수준에 따라 소득분위를 5 분위로 구분하여 분석하였다. 통계분석은 SAS 프로그 램을 이용하였다.

결과

소득1분위 집단은 입원진료실적은 가장 낮은 비율을 차지하는 반면, 외래진료 실적은 최근 2년간 증가추세를 보이는 가운데 가장 높은 비율을 차지하는 것으로 나타났다. 소득 1 분위는 유산, 전자간증, 자간증의 진료 비율이 높고, 분만은 적은 비율을 차지하였으며, 소득5분 위는 고령임부, 다태임신 비율이 높은 것으로 나타났다. 또한 소득수준이 높아질수록 대형병원의 입원 및 외래 이용률이 높은 것으로 나 타났다.

결론

본 연구결과, 소득계층별로 다빈도 산과질환 및 의료기관 이용이 차이를 보이는 것으로 확인되었다. 향후 대상자의 소득수준별 특성에 맞 는 산전관리프로그램이 필요하며, 특히 저소득층 임신부를 위한 제도적 지원 강화 방안 모색이 필요하다.

중심단어: 소득수준, 산과적 질환, 유산, 전자간증, 다태임신 